\title{
Multi-Criteria Prediction Framework for the Prioritization of Council Candidates based on Integrated AHP-Consensus and TOPSIS Methods
}

\author{
Nurul Akhmal Mohd Zulkefli ${ }^{1}$, Mukesh Madanan ${ }^{3}$ \\ Tariq Mohsen Hardan ${ }^{4}$ \\ Department of Computer Science \\ CAAS, Dhofar University \\ Salalah, Sultanate of Oman
}

\author{
Muhamad Hariz Muhamad Adnan ${ }^{2}$ \\ Computing Department \\ FSKIK, Sultan Idris Education University \\ Tanjong Malim, Malaysia
}

\begin{abstract}
Predicting the council candidate becomes difficult due to the large number of criteria that must be known and identified. The best candidate should be chosen from among the candidates because he or she will play an important role in the organization or institution. It is critical to find the right and best candidate these days because people see and judge the outcome from the candidate in a short time with the help of social media. Perhaps the organization and institution require the best candidate criteria because they will manage and organize the community around them. This study focuses on how to prioritize council candidates using Analytic Hierarchy Process (AHP) for determine the criteria and Technique for Order of Preference by Similarity to Ideal Solution (TOPSIS) for prioritize the student council candidate. This proposed framework based on MultiCriteria Decision Making (MCDM) will be used to recommend and assist students in selecting the best candidate for student council. The three criteria chosen were grade point average (GPA), Age, and Semester. Based on the results of the questionnaire and a review of the literature, these criteria were developed. The three criteria were then used to determine the most important criterion for selecting the student council. The AHP weight is used to determine and prioritize the most important criteria. TOPSIS was used to select the most qualified student council candidate. The findings show that GPA is the most important criteria in selecting the best candidate, and the TOPSIS findings support the AHP findings.
\end{abstract}

Keywords-Analytic hierarchy process (AHP); technique for order of preference by similarity to ideal solution (TOPSIS); multicriteria decision making (MCDM); student council

\section{INTRODUCTION}

Universities or institutions of higher learning (HLI) provide a variety of responsibilities, such as delivering a high-quality academic curriculum and involving students in extracurricular activities such as sports. It is critical to educate youngsters on the necessary leadership traits for nation-building and future leadership [1]. As a result, student representatives must be included in educational institutions' administrative structures [2]. The student representative committee (SRC) is a studentled organization that aims to foster a feeling of community and leadership among students [3].

Elections are democratic procedures in which the general public chooses a candidate for public office. Elections are crucial to every organization's development because they determine who will lead the people. "A person (a) whose name appears on the official ballot for election to the office of the representative in, or delegate or resident commissioner to, the congress," according to the definition. The student representative council (SRC) is an annual council of university students elected by their peers. Anyone who meets one or more of the following qualifications is eligible for SRC candidate status. Candidates can seek nomination or election via a petitioning method. The candidate can be anybody who wishes to run for office as a write-in candidate. Finally, the candidate also from anybody who selects a treasurer and designates a primary depository, as well as anyone who submits qualifying papers and administers a candidate's oath in compliance with relevant law, is exempt. The goals of this system are to design, implement, and test a web-based system for choosing candidates for the SRC election based on criteria provided by the university.

The proposed system focus on predicting the SRC candidates among students. Differences with other existing systems or methods, most of researchers focus on predicting the result of election. However, predicting the result has become common in the election area. The most important of the election is to get the best and most valuable candidate. The election will finish in one day but the effect of the wrong election result will give a long effect on people, as well as organizations or countries. To determine or predict the best SRC candidate, AHP methods are used to get the best criteria for choosing the candidate. The weight of criteria will be used in TOPSIS to rank and predict the best candidate based on the criteria chosen.

\section{LITERATURE REVIEW}

When it comes to communicating peers' opinions to the university and, more importantly, ensuring that their opinions are heard, the SRC plays a critical role. They are on the front lines of student welfare, and their opinions are representative of those of students and at the same time, they contribute to the educational environment on campus. Students that join in SRC become participants in the institution's internal decisionmaking process, enabling them to participate in the governance of the university [3]. The SRC must collaborate with the 
university's leadership to ensure that the university's mission and vision are accomplished. SRC members are responsible for student concerns and provide recommendations to the proper university departments, in addition, to serve as the front line of students' advocacy. Therefore, it can be stated that SRC plays an important function in HLI and is a significant stakeholder in the project because of this.

\section{A. Criteria on Student Council Candidate}

A strong leader is required for a team to efficiently manage its internal and external affairs as well as to organize teams toward respective objectives [4-5]. The team requires an effective leader who can offer support when necessary and foster interaction as well as trust among team members and also for the people who vote for the candidate. As a result, various research presented several criteria for selecting a strong leader. According to research conducted at Sultan Idris Education University [6], candidates become the primary determinant in being elected as the SRC, followed by their manifesto.

The selection criteria are the exact criteria that candidates must meet to be considered for a job or to fulfill a certain function. Examples of criteria include talents, skills, capacities, and knowledge, among others, but they may also include other characteristics [7]. Apart from that, candidates for the SRC are chosen based on their race, personality, looks, leadership, and academic skills. The research of [8] shows that race and personality are used as selection criteria. Their research revealed that personality traits such as educational attainment, philosophical alignment, and racial affinity were all important considerations in the hiring process, with the respondents giving preference to individuals who met these criteria.

According to the researcher, three qualities for candidates Commitment, Passion, and Well-organized - received a higher weighting than the other leading criteria. This showed that these three characteristics should be prioritized in the selection of SRC candidates. This research adds to our understanding of the SRC's new vote method, especially in terms of candidate screening. It also offers extensive conditions for SRC candidates, ranking those leadership attributes using the AHP technique [9]. The Student Representative Council (SRC) Election System and the Post Based on Selection Sort (Sorting Algorithm) have one thing in common: every school must have a field of applicants for the SRC position to be chosen by their students. The technique boosts voter participation during elections after a substantial shift, which is one of the benefits.

A project titled A Secure E-Voting for The Student Parliament was created by [10]. The project was built on a cryptographic algorithm and included the pre-election, voting, and election processes. The Student Representative Council (SRC) Election System and the Position Based on Selection Sort (Sorting Algorithm) are comparable in that they are both created for a population of students that is primarily made up of students sharing a common mindset as well as actual behavior. Unlikability, anonymity, and verifiability are all advantages. The drawbacks include increased usability, security, and voter distrust.
Finally, [11] students finished a project titled "Digital Democracy \& Student Politics: Interpretation from the Assam University Students Council Election," which focused on how social media might be utilized to convince voters. Both the Student Representative Council (SRC) Election System and the Position based on Selection Sort utilize the internet to encourage students to vote in elections. The benefit is that it gives people a one-of-a-kind chance to express themselves without constraint or interference. The disadvantage is that election management is a difficult undertaking on all fronts.

In this research, we focus on the Ministry of Education Oman's [12] criteria, which include credit hours completed (by semester) and a GPA of at least 2.0 out of 4 points for diploma and bachelor's students, as well as the university council's criteria, which include age as important criteria to consider when selecting candidates.

\section{B. AHP and TOPSIS}

Over the last several years, multiple criteria decision making (MCDM) approaches have gained in popularity and are now regularly employed in a broad variety of real-world settings [13-16, 30]. The Technique for Order Preference by Similarity to Ideal Solution (TOPSIS) proposed by is one of the most popular and widely used MCDM methods [17]. The strategy's underlying principle is straightforward. The so-called positive ideal solution (PIS) and the negative ideal solution (NIS) are used to construct benchmarks (NIS). There were two options considered, and both were chosen because they were closest to the PIS and farthest away from the NIS, respectively. When it comes to benefit and cost, the PIS and NIS are opposites. The PIS optimizes benefit while limiting expense, whereas the NIS maximizes both.

University of Kuala Lumpur students [18] employed the AHP method to increase their instructors' assessment scores. As a part of this study, researchers looked at what criteria contribute to a lecturer's overall performance as well as his or her credibility, as well as how these criteria are ranked based on significance. Because the criteria are weighted depending on importance, the proposed technique is more accurate at differentiating the performance of lecturers than the existing exercise, which takes the average of all criteria into account. Selecting the right SRC is critical because it reflects the good governance of universities [10]. In this study, the Analytic Hierarchy Process (AHP) approach is used to gather student society viewpoints on SRC leadership criteria and to determine which criterion is the most often used.

The Analytic Hierarchy Process (AHP) is used to rank the criteria that demonstrate the importance of dedication, enthusiasm, and organization. Student's curriculum vitae (CV), manifesto plan, and application form are considered as extra requirements in screening the SRC application. The procedure is crucial to ensure that the chosen SRC is competent and capable of fulfilling the expectations of their peers since they will represent the institution [19]. Normally, candidate selection in Malaysian public universities is done through an evaluation process conducted by the faculty/university, but this process is inefficient. Several criteria must be considered to avoid biases. As a result, this study employs the Analytical Hierarchy Process (AHP) method to identify and prioritize the 
criteria for selecting the best candidate among UPSI undergraduate students [20]. A common scenario is selecting an appropriate bachelor program and university by [21]. Sijil Tinggi Persekolahan Malaysia (STPM, Malaysian High School Certificate) leavers are a significant group of bachelor program prospect students in Malaysia. Prospective students made their decision based on a variety of criteria, including university requirements, personal preferences, and influences from parents, teachers, and peers. Decisions are typically unstructured and biased as a result of personal preferences and influencers.

Since the emergence of dynamic websites, all business operations of a commercial organization are usually connected with the firm's website. Therefore, a complicated and vast website has been created, which may result in sluggish downloads and difficult navigation. Meeting the demands of the end-user is one of the most fundamental criteria of developing a successful website. Because different users have varied expectations for a website, there are several criteria that the user needs to be satisfied with; hence, evaluating a website is a multi-criteria decision-making problem. The integration of Fuzzy TOPSIS and the Fuzzy Analytic Hierarchy (FAHP) technique to reduce uncertainties and ambiguity in decision making, in which the views of multiple decision makers (DMs) were used for ranking the website [23]. Moreover, another example study is done by [22] that used hybrid fuzzy AHPTOPSIS to create flood risk maps, hazard, and district-based vulnerability for Istanbul. In health care, example such as [24] examines and evaluates the usefulness of health information systems in the delivery of health care. A multi-criteria study of the efficiency of health information systems utilizing the AHPTOPSIS approach is used to evaluate electronic health care information systems based on three commonly used software.

AHP and TOPSIS are widely used and well-known in the decision making process. As so far, none integrated MCDM for AHP and TOPSIS is used in prioritizing the council candidates. Most existing research are focused on predicting the result of election compare to help people in deciding on choosing the correct candidates. Besides, predicting the election results are not relevant in this new era as people will look at the candidate's ability to lead the organization or community right after the candidate becomes the leader. So, based on the AHP and TOPSIS method, it can help people to choose the correct SRC candidate based on the criteria given while TOPSIS prioritizes the candidates and help people to choose wisely.

\section{RESEARCH METHODOLOGY}

This study had two stages (as shown in Figure1), which were carried out using a mixed-method approach that combined both qualitative and quantitative approaches. The first stage involved evaluating and selecting criteria from the questionnaire and conducting a literature review. Based on this step, three criteria were proposed: GPA, Semester, and Age. Following that, a student sample was collected and stored in the database.

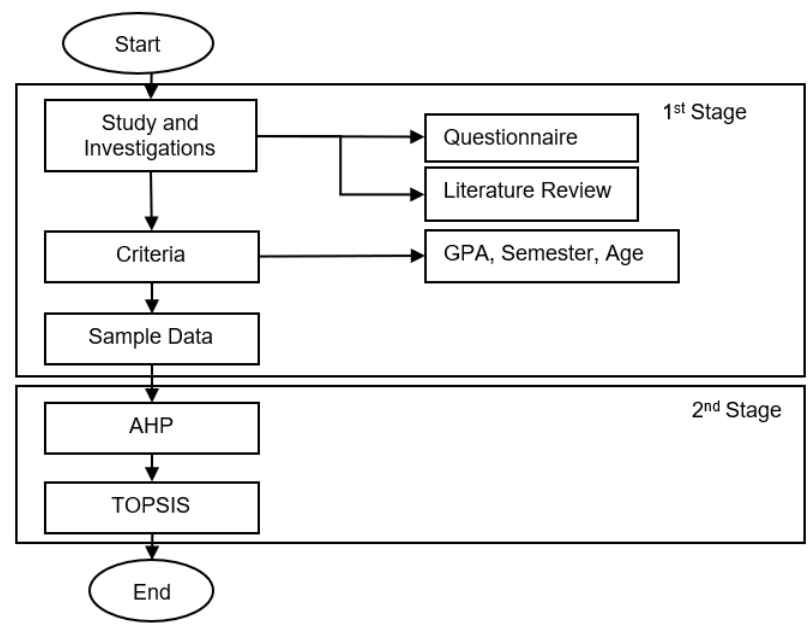

Fig. 1. Framework of Student Council Candidate based on AHP-TOPSIS.

In the second stage, the most important criteria for candidates are determined using AHP, and candidate rankings are based on TOPSIS. The questionnaire and literature review revealed that the criteria for candidates are GPA, Semester (Credit hours), and Age. These criteria were chosen following the discussion in the Literature Review. Meanwhile, sample data were collected by randomly selecting 100 students from a local university to provide input data based on the criteria proposed. After some of the students refused to share the information about their GPA after entering the biography data, the data was cleaned.

In the second stage, eight respondents were chosen to complete the AHP questionnaire to select the best criteria from three options. These respondents were chosen based on their background and experience in either a university setting or an academic setting. We implemented the AHP Balanced-n scale in the AHP method because [25-27] pointed out that integers from 1 to 9 yield local weights that are not evenly distributed.

The AHP indicator was used as shown in Table 1.

TABLE I. INTENSITY FOR AHP

\begin{tabular}{|l|l|l|}
\hline Intensity & Definition & Explanation \\
\hline 1 & $\begin{array}{l}\text { Equal } \\
\text { importance }\end{array}$ & $\begin{array}{l}\text { Two elements contribute equally to the } \\
\text { objective }\end{array}$ \\
\hline 3 & $\begin{array}{l}\text { Moderate } \\
\text { importance }\end{array}$ & $\begin{array}{l}\text { Experience and judgment slightly favor one } \\
\text { element over another }\end{array}$ \\
\hline 5 & $\begin{array}{l}\text { Strong } \\
\text { importance }\end{array}$ & $\begin{array}{l}\text { Experience and judgment strongly favor } \\
\text { one element over another }\end{array}$ \\
\hline 7 & $\begin{array}{l}\text { Very strong } \\
\text { importance }\end{array}$ & $\begin{array}{l}\text { One element is favored very strongly over } \\
\text { another, its dominance is demonstrated in } \\
\text { practice }\end{array}$ \\
\hline 9 & $\begin{array}{l}\text { Extreme } \\
\text { importance }\end{array}$ & $\begin{array}{l}\text { The evidence favoring one element over } \\
\text { another is of the highest possible order } \\
\text { affirmation }\end{array}$ \\
\hline $2,4,6,8$ can be used to express intermediate values
\end{tabular}


The row geometric mean (RGMM) approach is used to compute the priorities pi in each input sheet Using the $N \times N$ pairwise comparison matrix $A=a_{i j}$ as calculated in 1

$r_{i}=\exp \left[\frac{1}{N} \sum_{j=1}^{N} \ln \left(a_{i j}\right)\right]=\left(\prod_{i=1}^{N} a_{i j}\right)^{1 / N}$

Consistency index (CI) is supplied with an $\lambda_{\max }$ calculated primary Eigenvalue, either from the RGMM or the principal eigenvalue from the EVM as in 2.

$C I=\frac{\left(\lambda_{\max }-N\right)}{N-1}$

The Alonso/Lamata linear [28] is used to fit the result in CR:

$C R=\frac{\left(\lambda_{\max }-N\right)}{2.7699 N-4.3513-N}$

AHP consensus is obtained using Shannon alpha and beta entropy for all inputs. Between zero and one hundred percent, the consensus indicator shows how much agreement there is amongst decision-makers. (Complete agreement among the decision-makers). AHP consensus indicator $S^{*}$ is calculated using 4 .

$S^{*}=\left\lfloor M-\exp \left(H_{\alpha \min }\right) / \exp \left(H_{\gamma \max }\right)\right\rfloor /\left\lfloor 1-\exp \left(H_{\alpha \min }\right) /\right.$

$\left.\exp \left(H_{\gamma \max }\right)\right]$

With $M=1 / \exp \left(H_{\beta}\right) . \quad H_{\alpha, \beta, \gamma}$ is the $\alpha, \beta, \gamma$ Shannon entropy for the priorities of all $K$ decision makers/participants.

Interpretation of AHP consensus indicator $S^{*}$ is shown in Figure 2.

Following the AHP process, the sample 100 data will be analyzed using the AHP weight criteria to check if the criteria selected indicate the best candidate. The scores of the trust criteria were ranked in descending order using the TOPSIS technique, whereas the algorithms were rated in the opposite direction. In the TOPSIS technique, the score for each criterion was obtained by calculating the distance between it and the positive and negative ideal solutions. The score with the shortest geometric distance to the positive ideal solution and the largest geometric distance to the negative ideal solution would be the highest utilizing this method. The researcher followed the process of the TOPSIS technique based on [30] in this study.

\begin{tabular}{ll}
\hline$S^{*}$ & Consensus \\
\hline$\leq 50 \%$ & Very low \\
\hline $50 \%-65 \%$ & low \\
\hline $65 \%-75 \%$ & moderate \\
\hline $75 \%-85 \%$ & high \\
\hline$\geq 85 \%$ & Very high \\
\hline
\end{tabular}

Fig. 2. Indicator $S^{*}$ in AHP.
The first step is to build a normalized decision matrix. To make it easier to compare attributes, certain dimensional attributes were transformed to non-dimensional attributes. Matrix $\left(x_{i j}\right)_{m * n}$ to matrix $R=\left(r_{i j}\right)_{m * n} \quad$ uses the normalization method.

$r_{i j}=x_{i j} / \sqrt{\sum_{i=1}^{m} x_{i j}^{2} r_{i j}}$

for all $\mathrm{i}=1 \ldots \mathrm{n}$ and $\mathrm{j}=1 \ldots n^{m}$

This process yielded a new matrix $\mathrm{R}$, which is shown as follows.

$R=\left[\begin{array}{cccc}r_{11} & r_{12} & \cdots & r_{1 n} \\ r_{21} & r_{22} & \cdots & r_{2 n} \\ \vdots & \vdots & \vdots & \vdots \\ r_{m 1} & r_{m 2} & \cdots & r_{m n}\end{array}\right]$

Step 2: The weighted normalized decision matrix is constructed.

The weights from decision maker, denoted by $w=$ $w_{1}, w_{2}, \ldots, w_{j}, \ldots, w_{n}$ where $j=1, \ldots, n$. Throughout this stage, the normalized decision matrix was used to make decisions. To create the resulting matrix, each column of the normalized decision matrix $\mathrm{R}$ was multiplied by the weights in each row of the decision matrix and $w_{j}$ associated with each column. The weights in the set were all equal to one.

$\sum_{j=1}^{m} w_{j}=1$

Step 3: Determination of the ideal and negative ideal solutions

Two artificial alternatives were defined in this phase as $\mathrm{A}^{*}$ (the ideal alternative) and $A^{-}$(the negative ideal alternative):

$A^{*}=\left\{\left(\left(\max _{i}^{v_{i j \mid j \epsilon J}}\right),\left(\min _{i}^{v_{i j \mid j \epsilon J^{-}}}\right) \mid i=1,2, \ldots, m\right)\right\}$

$=\left\{v_{1}^{*}, v_{2}^{*}, \ldots, v_{j}^{*}, \ldots, v_{n}^{*}\right\}$

Where $J$ is a subset of $\{i=1,2, \ldots, m\}$, that has the benefit attributes (i.e., that provides rising utility as the value of I increases), and $J^{-}$is the complement set of $J$. Similarly, the cost-type attribute, as expressed by $J^{c}$ might have the opposite value added as well.

Step 4: Based on Euclidean distance, a separation measurement is calculated as follows. The separation measurement was carried out in this stage by computing the distance between each alternative in $\mathrm{V}$ and the ideal vector $\mathrm{A}^{*}$ using Euclidean distance, which is given by the equation below:

$S_{i^{*}}=\sqrt{\sum_{j=1}^{n}\left(v_{i j}-v_{j}^{*}\right)^{2}}, i=\{1,2, \ldots m\}$

Similarly, the separation measurement for each alternative in $\mathrm{V}$ from the negative ideal $A^{-}$is provided by the following equation:

$S_{i^{-}}=\sqrt{\sum_{j=1}^{n}\left(v_{i j}-v_{j}^{-}\right)^{2}}, i=\{1,2, \ldots m\}$ 
At the end of step 4, two values, namely, $S_{i}^{*}$ and $S_{i}^{-}$, for each alternative were counted. The distance between each alternative and the ideal and the negative ideal solutions is represented by these two values.

Step 5: Closeness to the ideal solution calculation

In this step, the closeness of $A_{i}$ to the ideal solution $A^{*}$ is defined as

$C_{i^{*}}=\frac{s_{i}}{\left(S_{i^{-}+} S_{i^{*}}\right)}, \quad 0<C_{i}<1, i=\{1,2, \ldots, m\}$

Obviously, $C_{i^{*}}=1$, if and only if $A_{i}=A^{*}$. Similarly, $C_{i^{*}}=0$ , if and only if $A_{i}=A^{-}$.

Step 6: Ranking of the alternatives based on the closeness to the ideal solution. The set of alternatives $A_{i}$ was now ranked according to the descending order of $C_{i^{*}}$, with the highest value indicating the best performance.

\section{A. Result and Analysis}

This section shows the outcomes of the individuals who were chosen based on their GPA, Semester, and Age. There are 100 applicants chosen, with $28 \%$ between the ages of 18 and $22,32 \%$ between the ages of 28 and 32 , and $40 \%$ between the ages of 23 and 27. As stated in Table II, 95 candidates are left for the next stage of the procedure after data cleansing.

\section{B. Weighted by $A H P$}

This section presents the data and decision-making results. Three criteria chosen are added to the AHP questionnaire and given to the eight experts. Table III shows the summarization of the respondents' responses.

The Weights acquired from the consensus indicator for group decisions are shown in Table IV. [29] is the one who introduces it. As a result, this group of 8 responders had a consensus $S^{*}$ of 70.6 percent. According to the AHP consensus index, there is a modest level of agreement among participants. The ranking result based on the criteria selected by all respondents (R1 - R8) is shown in Figure 3. Most respondents stated that the most significant criterion for Student Council candidates is a high GPA. The semester is the second most important criterion, and age is the third most critical criterion.

\section{Criteria Evaluation by TOPSIS}

TOPSIS is used to evaluate the alternatives based on the DM findings presented in Figure 4 and 5, which highlight the sensitivity of the evaluation criteria from the standpoint of each expert.

TOPSIS compares each option to the positive ideal (highest score) and negative ideal (lowest score) by determining the alternative's highest and lowest scoring results (lowest score). $\mathrm{S}$ - indicates how near an alternative is to the lowest score. S+, on the other hand, denotes how near an alternative is to the top score. The outcomes of the ranking contexts S- and S+ are shown in Table V.
TABLE II. SAMPLE DATA FOR CANDIDATES

\begin{tabular}{|c|c|c|c|c|c|c|c|}
\hline 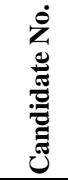 & 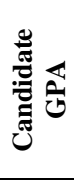 & 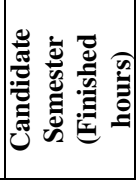 & 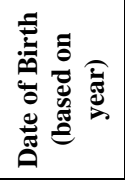 & 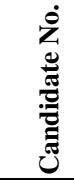 & 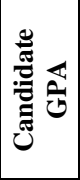 & 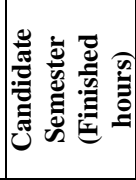 & 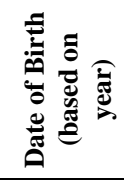 \\
\hline A1 & 80 & 20 & 1980 & A49 & \begin{tabular}{|l|}
86 \\
\end{tabular} & 56 & 1986 \\
\hline A2 & 71 & 110 & 1984 & A50 & \begin{tabular}{|l|}
76 \\
\end{tabular} & 78 & 2001 \\
\hline$\overline{\mathbf{A 3}}$ & 83 & 25 & 1989 & A51 & \begin{tabular}{|l|}
78 \\
\end{tabular} & 98 & 1980 \\
\hline A4 & 75 & 35 & 1988 & A52 & \begin{tabular}{|l|}
82 \\
\end{tabular} & 70 & 1999 \\
\hline$\overline{\mathrm{A5}}$ & 74 & 30 & 1992 & $\mathbf{A 5 3}$ & \begin{tabular}{|l|}
73 \\
\end{tabular} & 34 & 1985 \\
\hline A6 & 80 & 55 & 1990 & A54 & 65 & 25 & 1983 \\
\hline A7 & \begin{tabular}{|l|}
73 \\
\end{tabular} & 34 & 1989 & A55 & \begin{tabular}{|l|}
78 \\
\end{tabular} & 92 & 1996 \\
\hline$\overline{\mathrm{A8}}$ & 80 & 30 & 1995 & A56 & \begin{tabular}{|l|}
73 \\
\end{tabular} & 56 & 1984 \\
\hline A9 & 89 & 45 & 1985 & A57 & \begin{tabular}{|l|}
77 \\
\end{tabular} & 34 & 1986 \\
\hline A10 & \begin{tabular}{|l|}
79 \\
\end{tabular} & 78 & 1992 & A58 & 80 & 77 & 1995 \\
\hline A11 & \begin{tabular}{|l|}
89 \\
\end{tabular} & 81 & 1992 & A59 & \begin{tabular}{|l|}
80 \\
\end{tabular} & 15 & 2000 \\
\hline A12 & 70 & 89 & 1985 & A60 & 81 & 15 & 2001 \\
\hline A13 & 87 & 60 & 1990 & A61 & \begin{tabular}{|l|}
70 \\
\end{tabular} & 65 & 2001 \\
\hline A14 & \begin{tabular}{|l|}
78 \\
\end{tabular} & 92 & 1997 & A62 & 91 & 45 & 1993 \\
\hline A15 & 79 & 55 & 1987 & A63 & \begin{tabular}{|l|}
72 \\
\end{tabular} & 105 & 1993 \\
\hline A16 & 82 & 111 & 1996 & A64 & \begin{tabular}{|l|}
78 \\
\end{tabular} & 60 & 1998 \\
\hline A17 & 91 & 115 & 1996 & A65 & 80 & 34 & 2000 \\
\hline A18 & 88 & 72 & 1992 & A66 & \begin{tabular}{|l|}
87 \\
\end{tabular} & 34 & 2000 \\
\hline A19 & 76 & 102 & 1993 & A67 & \begin{tabular}{|l|}
70 \\
\end{tabular} & 89 & 1999 \\
\hline A20 & 80 & 88 & 1996 & A68 & \begin{tabular}{|l|}
73 \\
\end{tabular} & 89 & 2000 \\
\hline A21 & 84 & 101 & 1998 & A69 & 82 & 111 & 1994 \\
\hline A22 & 72 & 67 & 1993 & A70 & 90 & 90 & 1993 \\
\hline $\mathbf{A 2 3}$ & 81 & 60 & 1999 & A71 & \begin{tabular}{|l|}
79 \\
\end{tabular} & 15 & 2001 \\
\hline A24 & 79 & 43 & 1995 & A72 & \begin{tabular}{|l|}
68 \\
\end{tabular} & 27 & 2000 \\
\hline A25 & 90 & 88 & 1995 & A73 & \begin{tabular}{|l|}
62 \\
\end{tabular} & 83 & 1992 \\
\hline A26 & 92 & 76 & 1982 & A74 & \begin{tabular}{|l|}
87 \\
\end{tabular} & 117 & 1993 \\
\hline A27 & 92 & 114 & 1995 & A75 & 75 & 98 & 1998 \\
\hline 28 & \begin{tabular}{|l|}
74 \\
\end{tabular} & 87 & 1989 & A76 & \begin{tabular}{|l|}
80 \\
\end{tabular} & 98 & 1999 \\
\hline A29 & 70 & 28 & 1988 & A77 & \begin{tabular}{|l|}
89 \\
\end{tabular} & 60 & 1993 \\
\hline A30 & \begin{tabular}{|l|}
74 \\
\end{tabular} & 24 & 1992 & A78 & 81 & 83 & 1992 \\
\hline A31 & 82 & 102 & 1996 & A79 & \begin{tabular}{|l|}
78 \\
\end{tabular} & 102 & 1997 \\
\hline A32 & \begin{tabular}{|l|}
76 \\
\end{tabular} & 22 & 1996 & A80 & \begin{tabular}{|l|}
79 \\
\end{tabular} & 80 & 1997 \\
\hline A33 & 70 & 45 & 1994 & A81 & 82 & 76 & 1987 \\
\hline A34 & 72 & 62 & 1985 & A82 & \begin{tabular}{|l|}
73 \\
\end{tabular} & 87 & 1990 \\
\hline A35 & 83 & 76 & 1991 & $\mathbf{A 8 3}$ & \begin{tabular}{|l|}
80 \\
\end{tabular} & 93 & 1992 \\
\hline A36 & 88 & 77 & 2001 & $\mathbf{A 8 4}$ & \begin{tabular}{|l|}
87 \\
\end{tabular} & 36 & 2000 \\
\hline A37 & 72 & 43 & 1993 & A85 & \begin{tabular}{|l|}
73 \\
\end{tabular} & 65 & 1997 \\
\hline A38 & 92 & 102 & 1995 & A86 & \begin{tabular}{|l|}
78 \\
\end{tabular} & 67 & 1992 \\
\hline A39 & 74 & 56 & 1993 & $\mathbf{A 8 7}$ & 88 & 87 & 1997 \\
\hline A40 & 93 & 63 & 1988 & A88 & 86 & 76 & 1995 \\
\hline A41 & \begin{tabular}{|l|}
73 \\
\end{tabular} & 110 & 1993 & A89 & \begin{tabular}{|l|}
78 \\
\end{tabular} & 102 & 1992 \\
\hline A42 & 76 & 28 & 1975 & A90 & \begin{tabular}{|l|}
90 \\
\end{tabular} & 43 & 1998 \\
\hline A43 & 89 & 111 & 1991 & A91 & 83 & 15 & 2000 \\
\hline A44 & 66 & 66 & 1993 & A92 & 76 & 78 & 1994 \\
\hline A45 & 87 & 78 & 2000 & A93 & \begin{tabular}{|l|}
89 \\
\end{tabular} & 15 & 2000 \\
\hline A46 & 88 & 63 & 2000 & A94 & \begin{tabular}{|l|}
67 \\
\end{tabular} & 65 & 1997 \\
\hline A47 & 87 & 54 & 2000 & A95 & \begin{tabular}{|l|}
80 \\
\end{tabular} & 50 & 1994 \\
\hline A48 & 88 & 65 & 2000 & & & & \\
\hline
\end{tabular}


TABLE III. SUMMARY OF RESPONDENTS EXPERT FOR AHP

\begin{tabular}{|c|c|c|c|c|c|c|c|}
\hline 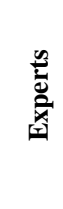 & Uू. & $C_{1}$ & $C_{2}$ & $C_{3}$ & 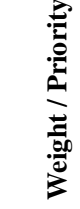 & 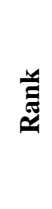 & 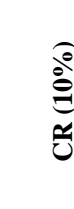 \\
\hline \multirow{3}{*}{ 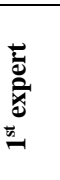 } & $C_{1}$ & 1.00 & 2.00 & 0.50 & 28.6 & 2 & \multirow{3}{*}{0.0} \\
\hline & $C_{2}$ & 0.50 & 1.00 & 0.25 & 14.3 & 3 & \\
\hline & $C_{3}$ & 2.00 & 4.00 & 1.00 & 57.1 & 1 & \\
\hline \multirow{3}{*}{ 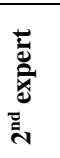 } & $C_{1}$ & 1.00 & 0.14 & 1.00 & 13.2 & 3 & \multirow{3}{*}{8.4} \\
\hline & $C_{2}$ & 7.00 & 1.00 & 3.00 & 69.4 & 1 & \\
\hline & $C_{3}$ & 1.00 & 0.33 & 1.00 & 17.4 & 2 & \\
\hline \multirow{3}{*}{ 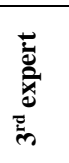 } & $C_{1}$ & 1.00 & 0.25 & 5.00 & 14.3 & 3 & \multirow{3}{*}{0.0} \\
\hline & $C_{2}$ & 4.00 & 1.00 & 2.00 & 57.1 & 1 & \\
\hline & $C_{3}$ & 2.00 & 0.50 & 1.00 & 28.6 & 2 & \\
\hline \multirow{3}{*}{ 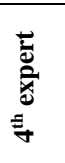 } & $C_{1}$ & 1.00 & 4.00 & 0.25 & 21.7 & 2 & \multirow{3}{*}{3.9} \\
\hline & $C_{2}$ & 0.25 & 1.00 & 0.11 & 6.6 & 3 & \\
\hline & $C_{3}$ & 4.00 & 9.00 & 1.00 & 71.7 & 1 & \\
\hline \multirow{3}{*}{ 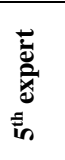 } & $C_{1}$ & 1.00 & 0.50 & 0.11 & 7.9 & 3 & \multirow{3}{*}{1.0} \\
\hline & $C_{2}$ & 2.00 & 1.00 & 0.17 & 14.3 & 2 & \\
\hline & $C_{3}$ & 9.00 & 6.00 & 1.00 & 77.9 & 1 & \\
\hline \multirow{3}{*}{ 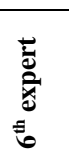 } & $C_{1}$ & 1.00 & 0.50 & 0.17 & 11.7 & 3 & \multirow{3}{*}{1.9} \\
\hline & $C_{2}$ & 2.00 & 1.00 & 0.50 & 26.8 & 2 & \\
\hline & $C_{3}$ & 6.00 & 2.00 & 1.00 & 61.4 & 1 & \\
\hline \multirow{3}{*}{ 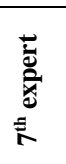 } & $C_{1}$ & 1.00 & 0.33 & 0.11 & 7.7 & 3 & \multirow{3}{*}{0.0} \\
\hline & $C_{2}$ & 3.00 & 1.00 & 0.33 & 23.1 & 2 & \\
\hline & $C_{3}$ & 9.00 & 3.00 & 1.00 & 69.2 & 1 & \\
\hline \multirow{3}{*}{ 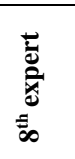 } & $C_{1}$ & 1.00 & 0.50 & 0.25 & 14.3 & 3 & \multirow{3}{*}{0.0} \\
\hline & $C_{2}$ & 2.00 & 1.00 & 0.50 & 28.6 & 2 & \\
\hline & $C_{3}$ & 4.00 & 2.00 & 1.00 & 57.1 & 1 & \\
\hline
\end{tabular}

TABLE IV. MATRIX OF NORMALIZATION WEIGHTS

\begin{tabular}{|c|c|c|c|c|c|c|c|c|c|}
\hline & $C_{1}$ & $C_{2}$ & $C_{3}$ & 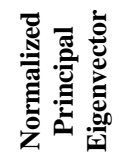 & 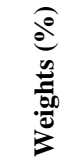 & $\frac{\sqrt{9}}{\frac{1}{+}}$ & 䒿 & $\begin{array}{l}\widehat{\theta} \\
\hat{\theta}\end{array}$ & 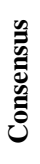 \\
\hline$C_{1}$ & 1 & $3 / 4$ & $1 / 2$ & $22.87 \%$ & 22.9 & 1.7 & \multirow{3}{*}{ 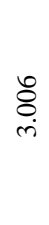 } & \multirow{3}{*}{$\stackrel{0}{0}$} & \multirow{3}{*}{8} \\
\hline$C_{2}$ & $\begin{array}{l}1 \\
1 / 3\end{array}$ & 1 & $3 / 4$ & $32.09 \%$ & 32.1 & 2.4 & & & \\
\hline$C_{3}$ & $\begin{array}{l}2 \\
1 / 8\end{array}$ & $11 / 3$ & 1 & $45.03 \%$ & 45.0 & 3.4 & & & \\
\hline
\end{tabular}

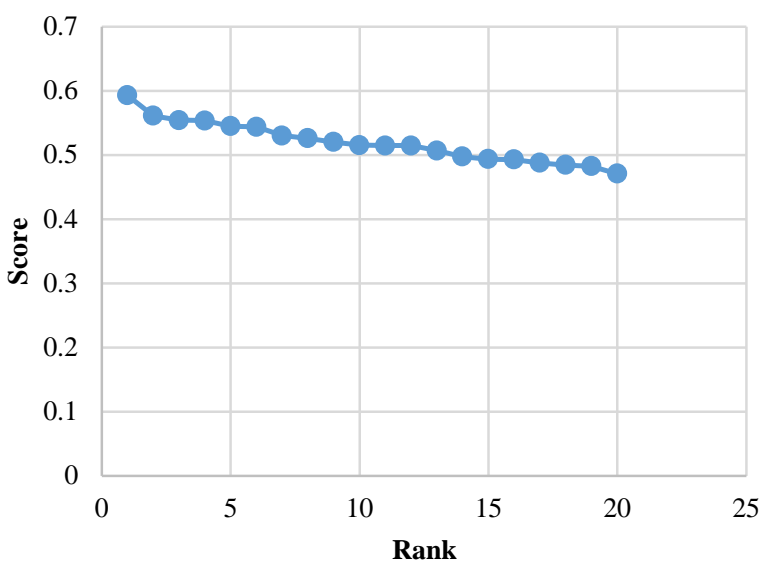

Fig. 3. Score Result for Top 20 Candidates.

$60.0 \%$

$50.0 \%$

$40.0 \%$

$30.0 \%$

$20.0 \%$

10.096

$0.0 \%$

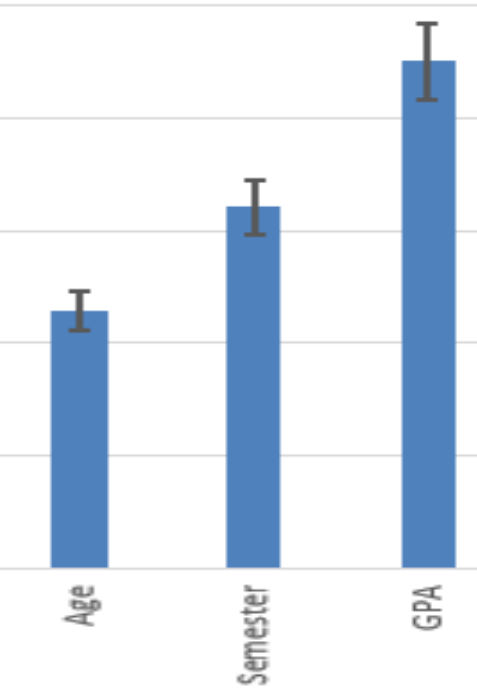

Fig. 4. Percentage Rank based on Criteria.

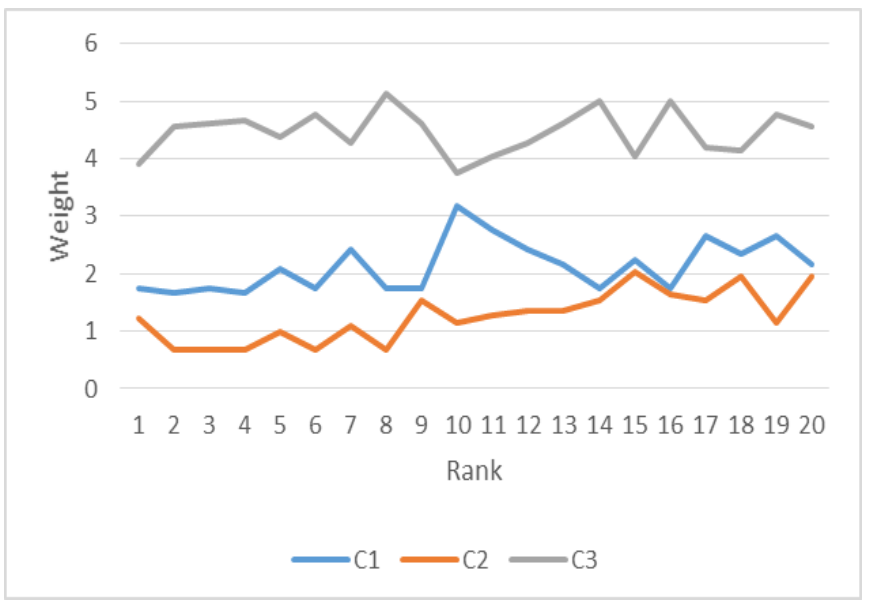

Fig. 5. Criteria Rank based on Weightage. 
TABLE V. CANDIDATE'S RANKING RESULT BASED ON THE EXPERT'S WEIGHTAGE

\begin{tabular}{|c|c|c|c|c|c|c|c|}
\hline \multirow{2}{*}{ 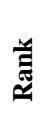 } & \multirow{2}{*}{ لِ } & \multicolumn{3}{|l|}{ Weight } & \multirow[b]{2}{*}{ S- } & \multirow[b]{2}{*}{ S+ } & \multirow{2}{*}{ 苞 } \\
\hline & & 22.9 & 32.1 & 45 & & & \\
\hline 1 & $\begin{array}{l}\text { A } \\
72\end{array}$ & $\begin{array}{l}1.75155 \\
5205\end{array}$ & $\begin{array}{l}1.2256 \\
9674\end{array}$ & $\begin{array}{l}3.92006 \\
9083\end{array}$ & $\begin{array}{l}2.29649 \\
7756\end{array}$ & $\begin{array}{l}3.34255 \\
5846\end{array}$ & $\begin{array}{l}0.59275 \\
121\end{array}$ \\
\hline 2 & $\begin{array}{l}\text { A } \\
71\end{array}$ & $\begin{array}{l}1.66814 \\
7814\end{array}$ & $\begin{array}{l}0.68092 \\
2041\end{array}$ & $\begin{array}{l}4.55419 \\
7905\end{array}$ & $\begin{array}{l}3.05022 \\
9475\end{array}$ & $\begin{array}{l}3.89573 \\
1594\end{array}$ & $\begin{array}{l}0.56086 \\
286\end{array}$ \\
\hline 3 & $\begin{array}{l}\mathrm{A} \\
59\end{array}$ & $\begin{array}{l}1.75155 \\
5205\end{array}$ & $\begin{array}{l}0.68092 \\
2041\end{array}$ & $\begin{array}{l}4.61184 \\
5979\end{array}$ & $\begin{array}{l}3.10595 \\
0806\end{array}$ & $\begin{array}{l}3.86108 \\
4259\end{array}$ & $\begin{array}{l}0.55419 \\
3315\end{array}$ \\
\hline 4 & $\begin{array}{l}\text { A } \\
60\end{array}$ & $\begin{array}{l}1.66814 \\
7814\end{array}$ & $\begin{array}{l}0.68092 \\
2041\end{array}$ & $\begin{array}{l}4.66949 \\
4054\end{array}$ & $\begin{array}{l}3.15954 \\
0153\end{array}$ & $\begin{array}{l}3.86108 \\
4259\end{array}$ & $\begin{array}{l}0.55362 \\
0266\end{array}$ \\
\hline 5 & $\begin{array}{l}\mathrm{A} \\
32\end{array}$ & $\begin{array}{l}2.08518 \\
4768\end{array}$ & $\begin{array}{l}0.99868 \\
566\end{array}$ & $\begin{array}{l}4.38125 \\
368\end{array}$ & $\begin{array}{l}2.82542 \\
7903\end{array}$ & $\begin{array}{l}3.37920 \\
0067\end{array}$ & $\begin{array}{l}0.54462 \\
5735\end{array}$ \\
\hline 6 & $\begin{array}{l}\text { A } \\
91\end{array}$ & $\begin{array}{l}1.75155 \\
5205\end{array}$ & $\begin{array}{l}0.68092 \\
2041\end{array}$ & $\begin{array}{l}4.78479 \\
0204\end{array}$ & $\begin{array}{l}3.27032 \\
5871\end{array}$ & $\begin{array}{l}3.89948 \\
4783\end{array}$ & $\begin{array}{l}0.54387 \\
556\end{array}$ \\
\hline 7 & $\begin{array}{l}\text { A } \\
30\end{array}$ & $\begin{array}{l}2.41881 \\
4331\end{array}$ & $\begin{array}{l}1.08947 \\
5266\end{array}$ & $\begin{array}{l}4.26595 \\
7531\end{array}$ & $\begin{array}{l}2.76531 \\
6883\end{array}$ & $\begin{array}{l}3.12125 \\
0424\end{array}$ & $\begin{array}{l}0.53023 \\
2691\end{array}$ \\
\hline 8 & $\begin{array}{l}\text { A } \\
93\end{array}$ & $\begin{array}{l}1.75155 \\
5205\end{array}$ & $\begin{array}{l}0.68092 \\
2041\end{array}$ & $\begin{array}{l}5.13067 \\
8652\end{array}$ & $\begin{array}{l}3.60148 \\
46\end{array}$ & $\begin{array}{l}3.99768 \\
1783\end{array}$ & $\begin{array}{l}0.52606 \\
8464\end{array}$ \\
\hline 9 & $\begin{array}{l}\mathrm{A} \\
65\end{array}$ & $\begin{array}{l}1.75155 \\
5205\end{array}$ & $\begin{array}{l}1.54342 \\
3293\end{array}$ & $\begin{array}{l}4.61184 \\
5979\end{array}$ & $\begin{array}{l}2.94751 \\
9616\end{array}$ & $\begin{array}{l}3.19500 \\
9582\end{array}$ & $\begin{array}{l}0.52014 \\
5608\end{array}$ \\
\hline $\begin{array}{l}1 \\
0\end{array}$ & $\begin{array}{l}\text { A } \\
54\end{array}$ & $\begin{array}{l}3.16948 \\
0847\end{array}$ & $\begin{array}{l}1.13487 \\
0069\end{array}$ & $\begin{array}{l}3.74712 \\
4858\end{array}$ & $\begin{array}{l}2.61926 \\
1648\end{array}$ & $\begin{array}{l}2.78448 \\
6773\end{array}$ & $\begin{array}{l}0.51528 \\
8011\end{array}$ \\
\hline $\begin{array}{l}1 \\
1\end{array}$ & $\begin{array}{l}\text { A } \\
29\end{array}$ & & & & $\begin{array}{l}2.63383 \\
7392\end{array}$ & & $\begin{array}{l}0.51461 \\
7048\end{array}$ \\
\hline 1 & $\begin{array}{l}\text { A } \\
5\end{array}$ & 2.41881 & $\begin{array}{l}1.36184 \\
408 ?\end{array}$ & $\begin{array}{l}4.26595 \\
7531\end{array}$ & 2.72138 & & 0.51454 \\
\hline $\begin{array}{l}1 \\
3\end{array}$ & $\begin{array}{l}\mathrm{A} \\
8\end{array}$ & $\begin{array}{l}2.16859 \\
2159\end{array}$ & $\begin{array}{l}1.36184 \\
4082\end{array}$ & $\begin{array}{l}4.61184 \\
5979\end{array}$ & $\begin{array}{l}3.00160 \\
3806\end{array}$ & $\begin{array}{l}3.08360 \\
4404\end{array}$ & $\begin{array}{l}0.50673 \\
7699\end{array}$ \\
\hline $\begin{array}{l}1 \\
4\end{array}$ & $\begin{array}{l}\text { A } \\
66\end{array}$ & $\begin{array}{l}1.75155 \\
5205\end{array}$ & $\begin{array}{l}1.54342 \\
3293\end{array}$ & $\begin{array}{l}5.01538 \\
2503\end{array}$ & $\begin{array}{l}3.35059 \\
5926\end{array}$ & $\begin{array}{l}3.31609 \\
6368\end{array}$ & $\begin{array}{l}0.49741 \\
2543\end{array}$ \\
\hline $\begin{array}{l}1 \\
5\end{array}$ & $\begin{array}{l}\mathrm{A} \\
33\end{array}$ & $\begin{array}{l}2.25199 \\
9549\end{array}$ & $\begin{array}{l}2.04276 \\
6123\end{array}$ & $\begin{array}{l}4.03536 \\
5232\end{array}$ & $\begin{array}{l}2.46676 \\
7121\end{array}$ & $\begin{array}{l}2.40191 \\
5148\end{array}$ & $\begin{array}{l}0.49333 \\
9884\end{array}$ \\
\hline $\begin{array}{l}1 \\
6\end{array}$ & $\begin{array}{l}\text { A } \\
84\end{array}$ & $\begin{array}{l}1.75155 \\
5205\end{array}$ & $\begin{array}{l}1.63421 \\
2899\end{array}$ & $\begin{array}{l}5.01538 \\
2503\end{array}$ & $\begin{array}{l}3.34844 \\
5674\end{array}$ & $\begin{array}{l}3.25396 \\
9767\end{array}$ & $\begin{array}{l}0.49284 \\
5353\end{array}$ \\
\hline $\begin{array}{l}1 \\
7\end{array}$ & $\begin{array}{l}\text { A } \\
7\end{array}$ & $\begin{array}{l}2.66903 \\
6503\end{array}$ & $\begin{array}{l}1.54342 \\
3293\end{array}$ & $\begin{array}{l}4.20830 \\
9456\end{array}$ & $\begin{array}{l}2.73308 \\
5352\end{array}$ & $\begin{array}{l}2.60017 \\
243\end{array}$ & $\begin{array}{l}0.48753 \\
9237\end{array}$ \\
\hline $\begin{array}{l}1 \\
8\end{array}$ & $\begin{array}{l}\text { A } \\
37\end{array}$ & $\begin{array}{l}2.33540 \\
694\end{array}$ & $\begin{array}{l}1.95197 \\
6518\end{array}$ & $\begin{array}{l}4.15066 \\
1381\end{array}$ & $\begin{array}{l}2.58624 \\
5751\end{array}$ & $\begin{array}{l}2.42999 \\
6051\end{array}$ & $\begin{array}{l}0.48442 \\
5621\end{array}$ \\
\hline $\begin{array}{l}1 \\
9\end{array}$ & $\begin{array}{l}\mathrm{A} \\
3\end{array}$ & $\begin{array}{l}2.66903 \\
6503\end{array}$ & $\begin{array}{l}1.13487 \\
0069\end{array}$ & $\begin{array}{l}4.78479 \\
0204\end{array}$ & $\begin{array}{l}3.31656 \\
7971\end{array}$ & $\begin{array}{l}3.09231 \\
8162\end{array}$ & $\begin{array}{l}0.48250 \\
4775\end{array}$ \\
\hline $\begin{array}{l}2 \\
0\end{array}$ & $\begin{array}{l}\text { A } \\
24\end{array}$ & $\begin{array}{l}2.16859 \\
2159\end{array}$ & $\begin{array}{l}1.95197 \\
6518\end{array}$ & $\begin{array}{l}4.55419 \\
7905\end{array}$ & $\begin{array}{l}2.94283 \\
6794\end{array}$ & $\begin{array}{l}2.61721 \\
155\end{array}$ & $\begin{array}{l}0.47071 \\
7409\end{array}$ \\
\hline
\end{tabular}

\section{CONCLUSION}

AHP is effectively employed in computing the objective weight based on the experiment results. The weights are derived from the expert preferences gathered using linguistic criteria. Another issue is that TOPSIS has successfully rated all the candidates based on the user's preferences and the estimated objective weight (see Table IV and Table V). The applicant with the highest rank (A72) obtained the highest score, followed by A71 and A69. The AHP application can help improve the student council selection process by determining the prevailing leadership criteria. When compared to other parameters, the results revealed that GPA, Semester, and Age are the most important.

Because of the successful examination of the AHP and TOPSIS methods, it can be concluded that these approaches can increase the quality of candidates for student council. The study's limitation is the modest size of the student community and expert panel. This research is expected to have a significant impact on future leadership development among organizations and institutions.

\section{REFERENCES}

[1] Hamid, J. A., \& Krauss, S. E. (2013). Does university campus experience develop motivation to lead or readiness to lead among undergraduate students? A Malaysian perspective. Journal of Student Affairs Research and Practice, 50(2), 208-225.

[2] Ahiatrogah, P. D., \& Koomson, A. K. (2013). Impact of perceived student leadership role on the academic performance of distant education students in Ghana. The Online Journal of Distance Education and e-Learning, 1(3), 26-34.

[3] Luescher-Mamashela, T. M. (2013). Student representation in university decision making: good reasons, a new lens?. Studies in Higher Education, 38(10), 1442-1456.

[4] Rou, C. J., Musa, D., \& Kamis, N. C. (2017). Students' Awareness towards the Student Representative Council: A Survey Conducted at Northern Region Polytechnics of Malaysia. 1(2), 14-22.

[5] Abed Aljasim Muhisn, Z., Omar, M., Ahmad, M., \& Adnan Muhisn, S. (2015). Team leader selection by using an Analytic Hierarchy Process (AHP) technique. Journal of Software, 10(10), 1216-1227.

[6] Boyman, S. N. (2017). Students and Campus Elections: Case study at Sultan Idris Education University, Malaysia. International Journal of Humanities and Social Sciences, 9(6), 32-45.

[7] O'Meara, B., \& Petzall, S. (2009). Selection criteria, skill sets and competencies: What is their role in the appointment of vice-chancellors in Australian universities?. International Journal of Educational Management., 23(3), 252-265

[8] Mohd Fuad, M.J., Junaidi, A.B., Abdul Halim S., Noor Aziah, M.A., (2011). Persepsi politik belia di kawasan Dewan Undangan Negeri (DUN) Bagan Pinang, Negeri Sembilan. [The political perception of the youths in the state assembly area of Bagan Pinang, Negeri Sembilan]. Malaysian Journal of Society and Space (Special Issue: Social and Spatial Challenges of Malaysian Development), 7, 105 - 115.

[9] Saaludin, N., Ismail, M. H., Abidin, I. S. Z., \& Mat, B. C., (2021). Application Of The Analytic Hierarchy (Ahp) Process For Evaluating Student Representative Committee (Src) Leadership Criteria, Asia Proceedings of Social Sciences, 5(2), 208-213.

[10] Pilipovic, D. M., \& Babic, D., (2016). A secure e-voting for the student parliament, Facta Universitatis, Series: Electronics and Energetics 29(2), 205-218.

[11] Mishra, R., (2016). Digital democracy and student politics: Interpretation from Assam university student's council elections, The Researcher: International Journal of Management, Humanities and Social Sciences, 1(01), 45-56.

[12] MOHE, The Organizational Manual of Student Advisory Councils in Higher Education Institutions, Sultanate of Oman (n.d.) Retrieved August 1, 2021 from https://www.nu.edu.om/contentfiles/SASElectionManual.pdf.

[13] Behzadian, M., Otaghsara, S. K., Yazdani, M., \& Ignatius, J. (2012). A state-of the-art survey of TOPSIS applications. Expert Systems with applications, 39(17), 13051-13069.

[14] Abdullah, L., \& Adawiyah, C. R. (2014). Simple additive weighting methods of multi criteria decision making and applications: A decade review. International Journal of Information Processing and Management, 5(1), 39-49.

[15] Kacprzak, D. (2020). An extended TOPSIS method based on ordered fuzzy numbers for group decision making. Artificial Intelligence Review, 53(3). 
[16] binti Mohd Zulkefli N.A., bin Baharudin B., bin Md Said A. (2018). Trust Blog Ranking Using Multi-Criteria Decision Analysis AHP and TOPSIS. In: Kim K., Kim H., Baek N. (eds) IT Convergence and Security 2017. Singapore.Lecture Notes in Electrical Engineering, 450.

[17] Hwang CL, Yoon K, (1981). Multiple attribute decision making: methods and applications. Springer, Berlin.

[18] Harun, S., Mat, B. C., Ismail, M. H., \& Saaludin, N. (2019). Improving Lecturers' Evaluation Score by Using Analytic Hierarchy Process (AHP): A case at Universiti Kuala Lumpur. Journal Electrical Engineering and Computer Science, 15(1), 391-398.

[19] Saaludina, N., Ismailb, M. H., Zainal, I. S., \& Abidinc, B. C. M. (2020). Analytic Hierarchy Process: The Improvement of the Student Representative Committee Selection Method at Universiti Kuala Lumpur. International. Journal of Innovation, Creativity and Change, 11(12), 719-741.

[20] Mohamed, A. (2021). Criteria For Selection Of The Best Student At Upsi Based On Analytical Hierarchy Process. Journal of Quality Measurement and Analysis JQMA, 17(1), 93-98.

[21] Yasin, S. N. S., \& Adnan, W. N. W. M. (2015). Bachelor Program and University Selection for STPM Leavers using TOPSIS. Jurnal Teknologi, 74(1).

[22] Ekmekcioğlu, Ö., Koc, K., \& Özger, M., (2021). Stakeholder perceptions in flood risk assessment: A hybrid fuzzy AHP-TOPSIS approach for Istanbul, Turkey, International Journal of Disaster Risk Reduction. 60, 102327.

[23] Nagpal, R., Mehrotra, D., Bhatia, P. K., \& Sharma, A., (2015) Rank university websites using fuzzy AHP and fuzzy TOPSIS approach on usability, International journal of information engineering and electronic business. 7(1), 29.

[24] Rađenović, Ž., \& Veselinović, I., (2017). Integrated AHP-TOPSIS method for the assessment of health management information systems efficiency, Economic Themes. 55(1), 121-142.

[25] Salo, A.,Hämäläinen, R., (1997). On the measurement of preferences in the analytic hierarchy process, Journal of multi-critria decision analysis. 6, $309-319$

[26] Goepel, K. D. (2019). Comparison of judgment scales of the analytical hierarchy process-A new approach. International Journal of Information Technology \& Decision Making, 18(02), 445-463.

[27] Goepel, K. (2018). Judgment scales of the analytical hierarchy process: the balanced scale. In International symposium of the analytic hierarchy process. Hong Kong.

[28] Alonso, Lamata, (2006). Consistency in the analytic hierarchy process: a new approach, International Journal of Uncertainty, Fuzziness and Knowledge based system. 14(4), 445-459.

[29] Goepel, K. D. (2013, June). Implementing the analytic hierarchy process as a standard method for multi-criteria decision making in corporate enterprises-a new AHP excel template with multiple inputs. In Proceedings of the international symposium on the analytic hierarchy process (Vol. 2, No. 10, pp. 1-10). Creative Decisions Foundation Kuala Lumpur.

[30] Zulkefli, N. A. M., \& Baharudin, B. (2015). Travel recommendation system based on trust using hybrid neuro-fuzzy: a study of potential trust in blog and Facebook. International Journal of Business Information Systems, 20(3), 289-309. 